\title{
PERSPECTIVES AND PRACTICES FROM INDONESIAN EFL TEACHERS ON LANGUAGE ADVISORS' ROLES IN FOSTERING LEARNER AUTONOMY
}

\author{
Muhamad Ahsanu ${ }^{1}$, Dyah Wijayawati \\ Universitas Jenderal Soedirman \\ $\underline{\text { ahsanu.muhamad@yahoo.com }}^{1}$, dyahwijayawati.sasindo@gmail.com $^{2}$
}

\begin{abstract}
Every teaching practitioner seemingly has come to a common term that language advising is essential in language learning especially in fostering language learner autonomy. However, the issue as to whether a teacher also plays the roles of an advisor or vice versa is still in controversy. This writing is not trying to claim which one is right and which one is not. This paper is just a little lantern on how actually the roles of a language advisor (LA) are exercised by teachers within the context of Indonesian EFL classrooms. Based on the data collected via interview suggest that they realized their role as a LA informally be it inside or outside their classroom practice. In actuating such LA roles, the teachers transformed into a motivator, awareness builder, student-teacher reflective practitioner, controller, and many times co-problem-solver. Presumably, the advising teachers in Indonesian setting not only feel responsible for transmitting knowledge and skills, but also for transforming ideas, advice, morality, values, etc. into their learners within and beyond classroom practices. The inkling of this paper is to descriptively address both theoretical and practical account of LA within the spectrum of learner autonomy.
\end{abstract}

Keywords: language advisor, learner autonomy, Indonesian EFL teachers

\section{Introduction}

Learning is a lifetime journey. Everyone lives with it, and school or university students are of no exception. What is challenging is not of what to learn, but learning how to learn in an independent way. This kind of learning is often referred to as autonomous learning or independent learning or self-directed learning (cf. Ohashi, 2018). So as to become autonomous learners and develop their language skills by undertaking the responsibility for their learning, students should be facilitated and guided in their learning process. This sort of teaching and guiding process especially in language learning is often called language learning advising and the people who are accountable for this task is labeled as language advisor (LA) (cf. Mynard, 2012).Advising in language learning can be defined as "a process of helping someone to become an effective, aware, and reflective language learner" (Kato \& Mynard, 2016:1). Generally, the prime goal of this advising is that students should be able to take control of their own learning, select appropriate learning activities suitable for their interests and needs and planning and performing their learning strategies functionally. This article attempts to look into what teachers (in this regard, Indonesian EFL teachers) think of the issues and the extent to which they have done the role of LA in a way to foster learner autonomy of their students.

By and large, language teachers in many parts of the world strive to foster learner autonomy or to stimulate the idea of autonomy in language classes. 
According to Orakc1 and Gelisli (2019), in order to develop autonomy in students, teachers should enable students to choose their learning duties, as well as supporting their students in identifying their interests, goals, and values. These certainly can create opportunities for students to learn autonomously. Sierens (2010) suggests that teachers can encourage students to self-assess, plan their activities, and enable them to think about themselves as learners. It means that teachers earnestly provide autonomy-supportive coaching. In classroom context, advising students to learn independently can imply how classroom teachers can provide support for learners to assist them in managing their learning beyond their face-to-face classes. Hence, this article approaches learner autonomy support from LA from the perspectives and practices of the Indonesian classroom teachers. In line with this, Blidi (2017) mentions that learner autonomy is not a solo journey and can be fostered through teacher support. The main aim of LA is to harness their capacity and willingness to act independently and in co-operation with others, as a social, responsible person in order to help them develop as autonomous learners (Benson, 2013). The objective is not only to help learners in exercising their ability and freedom, but also their desire to control their learning (Ushioda, 2011).

It is vastly upheld that learner autonomy in language learning is something highly recommended since learner autonomy is recognized as an essential principle of language learning (Orakcı \& Gelişli, 2017). Therefore, learner autonomy can be understood as the learners reflect on themselves and that they take responsibility for their own learning processes (Chang, 2020). For that meaningful idea, learner autonomy has been widely considered a vital indicator of successful language learning (Benson, 2011; Lamb, 2008; Sinclair, 2008; Ushioda, 2011). One of very concerned studies suggests that when students take on responsibility, they perform more meaningful and successful learning (Boyno, 2011). Many other research findings also indicate a similar point in which learner autonomy is considered as one of the desirable educational goals (Benson, 2007; Borg, 2012; Ramadhiyah \& Lengkanawati, 2019; Reinders \& White, 2016).

Another study which suggests that learner autonomy is an essential aspect in language learning was conducted by Chang (2020). In his study, Chang found that generally teachers value learner autonomy in language learning. This denotes that the teachers held a belief that learner autonomy is vital for their students' learning. Chang further exhibits learner autonomy can potentially promote life-long learning, enhance learning motivation and improve ability for self-reflection. There are at least twofold benefits for students if they exercise learner autonomy. Firstly, learners are enabled to develop a sense of co-ownership when working together with their peers (Peeters \& Mynard, 2019), and secondly, through learner autonomy, learners enacted their agency to capitalise on the affordances for language learning beyond the classroom (Benson, 2011).

The final study taken into account in this article was performed by Sofrac1 (2016) cited in Öztürk (2019) investigating the perceptions of EFL instructors and Turkish EFL pre-service teachers regarding learner autonomy. The findings indicate that the majority of the participants found themselves supportive in relation to promoting learner autonomy. Conclusively, learner autonomy is widely endorsed concept of empowering learners to learn independently. Irrespective of this 
promising state of developing and promoting learner autonomy in language learning, little research has been conducted on investigating and identifying the roles of language advisors (LA) to promote and foster learner autonomy particularly within the context of Indonesian educational institutions. Modestly, this study represents an attempt to address this gap.

Explanatory Question

This paper is projected to provide sensible answers for the following explanatory question:

"How do the Indonesian EFL teachers perceive and practice the roles of language advising in their classroom teaching and beyond for deriving autonomous learners?"

\section{Materials and Method}

Materials

\section{Paradigm shifts in language teaching}

The old paradigm suggesting that teacher's job is merely to teach is now nearly vanished. Teachers no longer transmit the soft-wire, the knowledge and skills, into the blank slates of learners; they no longer spoon-feed the empty pots of students' minds. Nowadays, teachers have changed to be, expectedly, transformative. In transmissive approach, as suggested by Miller (2019), teaching is the act of transmitting knowledge from Point A (teacher's head) to Point B (students' heads). This is a teacher-centered approach in which the teacher is the bearer of knowledge, the judge of truth, and the final evaluator of learning. A teacher's job from this perspective is to supply students with a chosen body of knowledge in a predetermined order. Conversely, in transformative perspective (Miller, 2019), teaching is creating conditions that have the potential to transform the learner on many different levels such as cognitive, emotional, creative, etc. The ultimate transformational goal is to help develop more nurturing human beings who are better able to perceive the interconnectedness of all human, plant, and animal life (Narve, 2001).

Learning takes place when experiences elicit a transformation of consciousness that leads to a greater understanding of and care for the self. Academic achievement from this transformational perspective is similar to self-actualization, perceived as discovering and developing each individual's unique talents and capabilities to the fullest extent possible. Self-actualization is synonymous with autonomous learner, 'the situations in which a learner, with others, or alone, is working without the direct control of a teacher' (Dickinson, 1987:5). This learning condition is aimed to attain a capability to perform learning independently, the end goal of a teacher as a LA. The primary role of teachers here is to enable students to discover and embrace their inner core and develop their interests and unique talents to the fullest extent to which students are engaged in meaningful learning experiences.

Current teachers have made a major shift from the position of teacher-centred to that of learner-cantered. In other words, they have migrated from the old comfort zone of transmissive practitioners towards the more flexible territory of transformative actors. Phrased differently, ideal teachers are not just teachers who teach, but teachers who teach as well as advise, termed as "Teacher Plus." The 
teachers who are actively engaged in the role of an advisor can better transform learners into more independent learners. Hence, advising teachers create autonomous learners, the ones who have 'the ability to take charge of their own learning effectively' (Holec, 1981:3). Advising is not about telling and showing the how-to tips. It is more on shedding the light for the learners in order for them to learn and develop their distinctive potentials. These can be developed in their own cognitive, affective and psychomotor aspects, which can lead to an effective and meaningful learning.

\section{Conceptualization of learner autonomy}

The idea of autonomous learning is defined as an act of learning whereby motivated learners consciously make informed decision about that learning (Mynard, 2011). It is simply about self-learning based on one's own appraisal of what, how and where to learn. It can be both formal and informal modes. In formal environment, learner autonomy can be incorporated in a variety of ways. This might be a simple focus on the development of good learning strategies or skills, a change in the way that learning activities or resources are organized, or in the way that the class operates (CIEL Project, 2000). Hence, the development of learner autonomy will depend crucially on:

'the initiatives the teacher takes ... therefore the first step he should take towards developing autonomy in his learners is to negotiate a joint interpretation of the syllabus with them.Such a process is more likely to succeed if it begins by inviting the learners to make explicit what they expect from the learning process and what they can bring to it, than if it begins with a lecture on the benefits of autonomous learning' (Little, 1995:45).

To develop the learners' autonomy effectively, Nunan (1997:194) suggests "a scheme for gradually increasing the degree of autonomy exercised by learners..." This envisages two domains: first, the experiential content domain (What) which has to do with topics, themes language functions, etc. with which the linguistic content makes up the syllabus. Second, the learning process is the domain (How) which has to do with learning tasks and procedures. Creating an environment that enables learners to develop in an autonomous way has a great importance in enhancing student motivation and confidence.

Another way to improve autonomy among students is to engage students in the decision-making process, particularly through activities that can enhance student motivation in the classroom (McGrath, 2013). Learner autonomy or self-directed learning can be promoted in many ways. One of which is through the cycles of Planning-Action-Reflection. The activities in these cycles may cover (Ohashi, 2018:237-238): 1) outline long-term and short-term goals; 2) identify tasks that will build towards goals; 3 ) list the tasks in a smart way; 4) discuss the plans in class; 5) take action outside of class; 6) discuss the action (or inaction...) in class; 7) reflect on the experience; 8) modify plans if necessary; and 9) continue the cycle. It can be said that this learning empowerment, empowering learners to learn autonomously, operates in circular developmental way.

\section{Conceptualization of language advising and language advisors}

Advising in language learning, or language advising, is a relatively new field in applied linguistics that has been attracting attention due to its focus on individual 
language learning trajectories (Castro, 2018; Kato \& Mynard, 2016; Mynard \& Carson, 2012). It aims to help learners to become more aware, reflective, and effective regarding their language learning, so they can become more autonomous, motivated and self-regulated learners (Ciekanski, 2007; Kato \& Mynard, 2016; Mozzon-McPherson, 2007). Through the advising process, the learner is encouraged to be an active agent, a protagonist in charge of choosing, constructing and evaluating learning plans with the support of a language advisor, a person who facilitates one's learning process, rather than directs it (Mynard, 2012).

Kelly (1996:94, cited in Mynard, 2011) espouses that advising as "a form of therapeutic dialogue that enables an individual to manage a problem." Advising is purported to provide guidance to students about their language learning and to encourage the development of learner autonomy (Reinders, 2008). It is focused on encouraging students to think about their language study and of ensuring that they are better prepared for their self-directed learning and thus more likely to succeed. Thus, language advisors are professional helpers in the domain of language learning aiming at empowering students to become self-directed learning. A learning advisor tends to work outside the classroom and outside class time and is available to work with individual learners on their needs (Mynard, 2011). Yet, having dedicated learning advisors available in addition to classroom teachers would be very helpful.

Reinders (2008) suggests that language advising is a form of language support that normally consists of one or more meetings (online or face-to-face) between an advisor (often a teacher or dedicated language support person) and a student, usually one-to-one, whose purpose is to provide guidance to students about their language learning and to encourage the development of learner autonomy. In the same vein, Mynard and Carson (2013) define advising in language learning as the process and practice of helping students to direct their own paths so as to become more effective and more autonomous language learners.

\section{Types of advising}

There are two types of advising (Smith, 2002): prescriptive and developmental (cited in Barbuto, et al. 2011:657). The traditional relationship between student and advisor is described as prescriptive, characterized by the advisor telling students what to do and students carrying on with the advice. Unlike prescriptive advising, developmental advising is marked by the development of the student and advisor relationship in varying degrees. The advisor here develops a stronger relationship with the advisee and they decide their roles within this relationship. Generally, the advising takes place in an extended session, which is negotiated and highly personalized (Reinders, 2008).

\section{Functions of learning advisors}

Learning advisors can bear an endless function. In general, there are ten identified functions that a learning advisor performs (Mynard, 2011:1). They include: raising awareness of the language learning process; guiding learners; helping learners to identify goals; suggesting suitable materials by offering choices (rather than prescribing activities); suggesting suitable strategies by offering choices, motivating, supporting and encouraging self-directed learners; helping learners to self-evaluate and reflect; assisting students in discovering how they best learn; actively listening to learners; and helping learners to talk through their own problems. In general, 
advisors use many different skills during their reflective dialogue with learners. Learning advisors usually employ both macro and micro skills (Rutson-Griffiths and Porter, 2016). The macro skills that support the institutional agenda, that is to develop autonomy and management of the advising sessions, while micro skills are concerned with reflective listening and building rapport with the learners.

\section{Position of learning advisors and roles of teachers}

There has been a misunderstanding about the roles of a teacher and an advisor. Some people believe that they play the same roles while others think that they are different and therefore play different roles. Rutson-Griffiths and Porter (2016:260) note a common misconception about advisors that they give advice to learners about immediate problems encountered during language study, the kind of assistance that classroom teachers already provide. Rutson-Griffiths and Porter suggest that although it may be the case that immediate problems are addressed during an advising session, one of the advisor's aim is to encourage reflection about the learning process so that learners ultimately become able to manage their own learning more effectively (p. 261).

Having a teacher who serves as a LA sounds ideal. However, it is often counterproductive since a teacher has already had his or her own workload that needs optimizing. When he or she handles two roles at the same time, it is always the case that when one is exercised, it is in the expense of the other. Hence, having separate an independent LA available in full-time mode in schools sounds better. An LA tends to work outside the classroom and outside class time and is available to work with individual learners on their needs. Different from language classes that are compulsory, offering learners the opportunity to discuss their learning outside of class can and should be voluntary (Mozzon-McPherson, 2007). This indicates that the learners themselves take the ownership for making their own decisions, including the decision about searching for help in the first place.

\section{Method}

This research used qualitative research approach in which, according to Silverman (2016), it is as much about social practices as about experiences, which has explanatory values. This denotes that the research is focused on explaining and describing the perspectives and practices of Indonesian EFL practitioners in terms of their roles as language advisors in fostering learner autonomy. The data were taken from 3 EFL practitioners through structured interview (see Appendix I). The participants are English lecturers in three different universities (one in a public and the rest in private universities). They have been teaching linguistics and applied linguistics subjects there for 10 to 20 years. They also teach in some other institutions. They are all graduates of British universities for their $\mathrm{Ph} . \mathrm{D}$ degree programs. The interview results were then transcribed and edited, but not translated as they are English teachers and the interviews were done in English as well. Afterwards, the findings were categorized based on the seven main items of the interview considered to directly provide adequate explanation to the research question. The data were then analyzed and interpreted descriptively and explanatorily. 


\section{Results and Discussion}

The discussions are classified into two sections based on three exploratory questions mentioned earlier. All the discussions are based on the results of interviews. The discussion, however, does not cover the whole question items due to limited space. The discussions entirely focus on the single exploratory question below.

How do the Indonesian EFL teachers perceive and practice the roles of language advising in their classroom teaching and beyond for deriving autonomous learners?

The answers to this question are categorized from items 3 to 16 of the interview questions (see Appendix I).

Being a LA in addition to a language teacher formally or informally

The three interviewees mentioned that they had never been formally assigned as a LA in their institutions. However, each of them confessed that once a while they played the role informally when they did teaching. The common case was that they had to provide answers and guidance to their students be it in class or outside the class. In particular, interview 3 stated that he often had to correct students' words, grammar in writing and pronunciation in speaking. Many of the Indonesian students are shy to speak or not confident to speak English probably because of being afraid of making mistakes. Therefore, interview 3 encouraged their students to be confident to express their ideas, feelings and intention in English since making mistakes in language learning is natural and normal.

Areas and ways of advising

In principle, all of the interviewees have helped students in many areas of language learning. There were at least five most frequently asked areas: speaking, grammar, translation, vocabulary and writing. Many of the students in Indonesia have problems in speaking. They might have learnt the sentence patterns but they cannot smoothly express it in their conversation. Consequently, their speaking ability develops quite slowly. All these LAs applied Smith's (2002) types of advising, namely: prescriptive and developmental (cited in Barbuto, et al. 2011:657). Hendra (Interviewee 1, see Appendix I) often faced this situation where his students eagerly wanted to be able to speak the language fluently. Usually, he motivated his students to speak freely without considering right or wrong sentences they might produce.

The other areas where Hendra was often involved in were on grammar and translation. It is true that to translate correctly one has to learn very well how sentences are construed grammatically. Therefore, when he was advising about translation, he was also advising on grammar. He also advised his students to watch youtube to learn how native speakers speak their language so that the students can imitate them as near as possible. Yudi had another focus (vocabulary) when doing the advising. His students were wondering how to keep as many words as possible in their mind which can help them in reading and writing. What he suggested was something strategic and creative. According to him, the best ways to increase our vocabulary were by writing the new words on papers then stuck them on tables, walls, and windows in their own rooms or houses so that students could see them easily every day.

In terms of speaking, Yudi (interviewee 2, see Appendix I) advised his students to have someone to talk to on daily basis. Interview 3 was focused on 
students' writing ability. He said that it is important for students to be able to construct correct sentences, write ideas, and compose a paragraph or an essay. Thus, all of the interviewees shared the same ideas that students need proper advice in certain areas in language learning. Those areas are actually interconnected one another.

\section{Raising the awareness of the learners about the importance of learning process}

There were three different areas of language awareness the interviewees advised to their students. They included 1) awareness of the importance of practice, 2) awareness of English values and 3) awareness of good writing. According to Hendra, students have to be aware that language learning is very challenging. Language learning, in his view, is not a matter of reading books or watching videos then they become proficient users of English. He adds that language is mostly a skill; therefore, students have to take time and pain practicing their language. Without which language will not result anything and will not improve anything.

The second awareness, values of English, highlights added values students can gain from understanding English well. Yudi took an example of invaluable information contained in newspapers, which students will never grasp if they learn English very poorly. This is true since most of the science and technology are stored in English archives. Many recent invention and research findings are recorded in English. Hence, if students learn English well, they can access those knowledge and information easily and they can cope with current trends and advancement of science and technology.

The last awareness was focused on the ability to write logically and structurally correct. If students, he asserts, do not master English well, especially in academic writing, they will find it hard to express their ideas clearly and meaningfully. Thus, mastering English properly is a demand in current decades that can help students to keep tract on scientific discovery and academic enhancement. This certainly further arouse and develops students' perspectives on science and technology development.

Helping to identify learners' learning goals

All of the interviewees came to a common term that they have helped their learners to identify their learning goals. Coincidentally, their learning goals happened to be the same mostly, that is, they learn English in university because they wanted to be an English teacher at school. Some other deviated yet related goals were that they wanted to go abroad, they wanted to get Master degree overseas, and they wanted to go travelling. The second interviewee, especially, strongly reminded their students to have a good mastery of English so they could be a good teacher at school. Consequently, all attributes of a good English teacher should be in their mind right from the beginning of their pre-service language learning.

Suggesting suitable materials (matching learners' needs) by offering choices

Two of the interviewees did involve their students in deciding what materials to teach. For instance, Hendra, he always asked their students in the first meeting regarding, for example, the reading materials that they were interested in. He just offered some topics and let their students decide what sort of materials they wanted to learn. They used the so-called negotiated and highly personalized approaches 
(Reinders, 2008). Here, it is important to keep students' interest and attention to contents of the reading materials. Hendra wanted his students to be more engaged in the classroom. Therefore, in most of his teaching activities, he usually used studentcentred approach, where students' needs and interest are put above the teachers.

The third interviewee also did a similar thing. He always tried to intensely involve his students in deciding what to learn, how to learn and how to evaluate especially in the first meeting. He used to do so-called "student needs analysis" in the hope that his class would run smoothly as all related technical aspects have already been settled down. Different from the other two interviewees, Yudi openly declared that he has never done it, never involved his students in any subject related decisions. He assumed that he knew what his students wanted as he used to be a student and knew the psychology of the students. Thus, he simply took the role of a controller in this respect. Yet, he admitted that it could be a good idea to involve students in curriculum decisions in the future in the hope that the students would learn what they actually want to learn.

Helping learners to do self-evaluation and reflection on their language learning

There were two interviewees who claimed that they asked their students to do a kind of self-evaluation. Hendra, for instance, said that he always asked his students to talk to their peers and ask for the input from them concerning the weaknesses so they could know what to improve in the future. The input could come from different individuals who could provide different evaluation for improvement. Another way of doing this, in Hendra's view, was by asking students to read some reading passages and to answer some comprehension questions and see how many were correctly or wrongly answered.

The second opinion, from Anton (interviewee 3, see Appendix I), espouses that he asked students to make some written 'reflection' about what they have learnt successfully, what they have failed to learn, what they have understood clearly and what they have not been able to understand. This is in conjunction with the advisor's aim, which is to encourage reflection about the learning process so that learners ultimately become able to manage their own learning more effectively (RutsonGriffiths \& Porter, 2016:261). In this way, the teacher would have a clearer idea regarding the appropriate area that needs enhancing and what is not. Unlike interviewees 1 and 3, Yudi boldly stated that he did not ask his students to do a selfevaluation. He just did it himself since he was not quite familiar with the procedures of self-evaluation.

Active listening to learners' voices

All of the interviewees have similar points where they were actively listening to their students' voices. Since the number of students in a class sometimes exceeded 100 students, according to Hendra, he could not listen to every individual. Normally, he would consider the voice of the class. If, for example, the class voice wanted him to teach them about a certain topic, then he would take that into account. Yudi also performed a good listening in which he tried not to be tempted to correct every single sentence or to identify all mistakes in his students' talk. He focused more on the message delivered. Anton did the listening through students' writing. He tried to make notes on what his students put in their writing. He tried to find a good way out for any situation faced by his students. 
Giving solutions for learners' learning problems or helping them discover their own solutions

The three interviewees shared quite similar ideas. They differed in their actualization. Interviewee I, for instance, would not leave his students with unsolved problems. He had to give them his solutions first. If the offered solutions did not match students' cases, then he would help them discover their own solutions. So, it really depends on two things: the nature of the problem and the kind of solutions they sought. According to Yudi, students came to us because they needed our solutions so we had to give the solution to them. Since we used to be a learner and now become a teacher, we heavily rely on our experiences. Anton had a slightly different conception. In his view, very few students could solve their own problems. Even if they got solutions from us, they seemed reluctant to do it. They tried to gain compensation for not doing what they were supposed to do.

Urgency of having LA at every school / university formally or embedded within the roles of language teachers

Hendra believed that LA is needed in both schools and universities. Yet, this role should be set formally and separately. It is not a part of teachers' job. Teacher should focus on their classroom teaching and learning. This LA does not only work in the classroom but can be anywhere. Logically, an LA should be someone who is not a teaching practitioner.

In line with Hendra, Yudi spelled out that in Indonesia, the schools can have language advisors (LAs) but the LAs should come from their own institutions to prevent a sense of gap, having not good feeling from within, the teachers inside. Otherwise, they will question the different status between the advisors and them. According to Anton, autonomous learning is not just about how the learners learn autonomously, it is related with ideas that they can reach. To create an autonomous learning atmosphere, he asserts, the institution should also provide materials or resources such as hard copy resources, soft copy resources, or just links to other resources. He suggested that the institution should build a mechanism to improve students' learning autonomy.

\section{Conclusion}

Based on the foregoing discussion, it can be inferred that the idea of establishing learner autonomy cannot be separated from the profession of language advisors whose jobs and responsibility are to ensure that the mechanism of autonomous learning run properly in schools and universities. There are few students who can be autonomous learners without direct guidance and supervision from language advisors. However, the majority of students rely on the caring hands of language advisors. Therefore, both schools and universities should have sufficient language advisors ready to hand an encouraging support and assistance for students. This even becomes more fitting for Indonesian schools and universities where English serves as a foreign language where it is not used as a means of daily communication and a means of classroom instruction. Many of Indonesian students learn English better not in schools or universities but in informal language courses offering more dynamic classes with intensive care and guidance of well-trained language advisors. If the very notion of learner autonomy is wished to run effectively 
where students are 'capable of taking charges of their own learning' (Holec, 1981:3), all stakeholders concerned have to have a shared idea of the important values LAs can bring about for the success of students' learning and education in the future. To end, if the first option, having separate Las, gets stuck, then teachers, though not particularly assigned for acting as LA, can and should be equipped with knowledge and skills of professional LA. At least, they can teach with a great care pride.

\section{References}

Barbuto, J. E., Story, J. S, Fritz, S. M. \& Schinstock, J. L. (2001). Full range advising: Transforming the advisor-advisee experience. Journal of College Student Development, 52(6), 656-670.

Benson, P. (2007). Autonomy in language teaching and learning. Language Teaching, 40(1), 21-40. https://doi.org/10.1017/S0261444806003958

Benson, P. (2011). Teaching and researching autonomy in language learning (2nd Ed.).London: Longman.

Benson, P. (2011). Language learning and teaching beyond the classroom: An introduction to the field. In. P. Benson, \& H. Reinders (Eds.), Beyond the language classroom (pp. 7-16). Basingstoke, UK: Palgrave Macmillan.

Benson, P. (2013). Learner autonomy. TESOL Quarterly, 47(4), 839-843. https://doi.org/10.1002/tesq.134

Blidi, S. (2017). Collaborative learner autonomy. Singapore: Springer.

Borg, S., \& Al-Busaidi, S. (2012). Learner autonomy: English language teachers' beliefs and practices. ELT Journal, 12(7), 1-45. https://www.teachingenglish.org.uk/article/learnerautonomy-english-language-teachers $\%$ E2\% $80 \% 99$-beliefs-practices

Boyno, M. (2011). An analysis of the factors influencing learner autonomy in the Turkish efl context (Doktora tezi). https://tez.yok.gov.tr sayfasından erişilmiştir.

Castro, E. (2018). Complex adaptive systems, language advising, and motivation: A longitudinal case study with a Brazilian student of English. System, 74, 138-148. https://doi.org/10.1016/j.system.2018.03.004

Chang, L. Y. (2020). Taiwanese EFL Language Teachers' Beliefs and Actual Practices Related to Learner Autonomy. TESL-EJ, 23(4), 1-15.

Ciekanski, M. (2007). Fostering learner autonomy: Power and reciprocity in the relationship between language learner and language learning adviser. Cambridge Journal of Education, 37(1), 111-127. https://doi.org/10.1080/03057640601179442

CIEL PROJECT (2000). 'Integrating independent learning with the curriculum'. In LLAS Good Practice Guide. Available at: http://www.lang.ltsn.ac.uk/resources/goodpractice.aspx?resourceid=1400

Dickinson, L. (1987). Self-instruction in Language Learning. Cambridge: Cambridge University Press.

Kelly, R. (1996). Language counseling for learner autonomy. In Mynard, J. (2011), The role of the learning advisor in promoting autonomy. Published in Learner Autonomy in Language Learning (http://ailarenla.org/lall).

Holec, H. (1981). Autonomy and Foreign Language Learning. Oxford: Pergamum Press.

Kato, S., \& Mynard, J. (2016). Reflective dialogue: Advising in language learning. New York, NY: Routledge.

Lamb, T.E. (2008). Learner and teacher autonomy: Synthesizing an agenda. In T.E. Lamb \& H. Reinders (Eds.), Learner and teacher autonomy: Concepts, realities and response (pp. 269284). Amsterdam: John Benjamins.

Little, D. (1995). 'Learner Autonomy 1: Definitions, Issues and Problems'. Authentic: Dublin.

McGrath, I. (2013). Teaching materials and the roles of EFL/ESL Teachers: Practice and Theory. London: Bloomsbury.

Miller, J.P (2019) The Holistic Curriculum. ( ${ }^{\text {rd }}$ Ed.). Toronto: University of Toronto Press. 
Mozzon-McPherson, M. (2007). Supporting independent learning environments: An analysis of structures and roles of language learning advisers. System, 35, 66-92. https://doi.org/10.1016/j.system.2006.10.008

Mynard, J., \& Carson, L. (Eds.). (2012). Advising in language learning: Dialogue, tools and context. Harlow, UK: Pearson.

Mozzon-McPherson, M. (2007) 'Supporting Independent Learning Environments: An analysis of structures and roles of language learning advisers' In J. Rubin (Ed.) Counselling in Language Learning Settings, Special Issue of System, 35(1), 66-92

Mynard, J. \& Carson, L. (2013). Advising in language learning: Dialogue, tools and context. New York: Rutledge.

Mynard, J. (2011). The role of the learning advisor in promoting autonomy. Published in Learner Autonomy in Language Learning (http://ailarenla.org/lall).

Narve, R.G. (2001). Holistic education: Pedagogy of universal love. Brandon, VT: Foundation for Educational Renewal.

Nunan, D. (1997). 'Designing and adapting materials to encourage learner autonomy'. In Benson B. and P. Voller (eds.) Autonomy and independence in language learning. Longman: Harlow, Essex.

Ohashi, L. (2018). Self-directed learning and the teacher's role: Insights from two different teaching contexts. In P. Taalas, J. Jalkanen, L. Bradley, \& S. Thouësny (Eds.), Future-proof CALL: Language learning as exploration and encounters - short papers from EUROCALL 2018 (pp. 236-242). Dublin, Ireland: Research-publishing.net. https://doi.org/10.14705/rpnet.2018.26.843

Öztürk, G. (2019). Fostering Learner Autonomy Among Pre-Service EFL Teachers: A Mixed-Method Study. International Journal of Educational Psychology, 8(3), 298-316.doi: 10.17583/ijep.2019.4427

Orakc1, S., \& Gelişli, Y. (2019). The Effect of the Application of Learning Activities Based on Learner Autonomy on the 6th Grade Students' English Achievements, Attitudes, and Learner Autonomy. International Journal of Curriculum and Instruction (IJCI), 11(1), 269-292. Available online at ijci.wcci-international.org

Peeters, W., \& Mynard, J. (2019). Peer collaboration and learner autonomy in online interaction spaces. Relay Journal, 2(2), 450-458. Retrieved from https://kuis.kandagaigo.ac.jp/relayjournal/issues/sep19/peeters_mynard/

Ramadhiyah, S., \& Lengkanawati, N. S. (2019). Exploring EFL learner autonomy in the 2013 curriculum implementation. Indonesian Journal of Applied Linguistics, 9(1), 231-240. https://doi.org/10.17509/ijal.v9i1.15626

Reinders, H., \& White, C. (2016). 20 years of autonomy and technology: How far have we come and where to next? Language, Learning \& Technology, 20(2), 143-154. https://scholarspace.manoa.hawaii.edu/bitstream/10125/44466/1/20_02_reinderswhite.pdf

Reinders, H. (2008). 'The what, why, and how of language advising' In: MexTESOL, 32(2). RutsonGriffiths, Y., \& Porter, M. (2016). Advising in language learning: Confirmation requests for successful advice giving. Studies in Self-Access Learning Journal, 7(3), 260-286.

Sierens, E. (2010). Autonomy-supportive, structuring, and psychologically controlling teaching: Antecedents, mediators, and outcomes in late adolescents (Doktora Tezi). Katholieke Universiteit Leuven, Leuven.

Silverman, D. (2016). Introducing qualitative research. In D. Silverman (Ed.), Qualitative research ( $4^{\text {th }}$ Ed.). London: SAGE

Sinclair, B. (2008). Multiple voices: Negotiating pathways toward teacher and learner autonomy. In T.E. Lamb \& H. Reinders (Eds.) Learner and teacher autonomy: Concepts, realities and response (pp. 237-268). Amsterdam: John Benjamins.

Sofrac1, G. (2016). Perceptions of EFL Instructors And Turkish EFLStudents As Prospective Teachers About Learner Autonomy And The Comparison Of Their Perceptions (Unpublished MA Thesis). Pamukkale University, Turkey.

Ushioda, E. (2011). Why autonomy? Insights from motivation theory and research. Innovation in Language Learning and Teaching, 5(2), 221-32. 
Perspectives And Practices From Indonesian Efl Teachers On Language Advisors' Roles In

Fostering Learner Autonomy

Muhamad Ahsanu, Dyah Wijayawati

Ushioda, E. (2011). Language learning motivation, self and identity: Current theoretical perspectives. Computer Assisted Language Learning, 24(3), 199-210. https://doi.org/10.1080/09588221.2010.538701

\section{APPENDIXES}

Appendix I: Interview question items

Date: January - March 2019

Length of interview: 1 hour

Teacher 1: Hendra (Anonym)

Teacher 2: Yudi (Anonym)

Teacher 3: Anton (Anonym)

Structured Interview on"Perspectives and Practices from Indonesian EFL Teachers on Language Advisors' roles in fostering Learners' Language Learning Autonomy"

This interview is focused on the following 18 questions which serve as the basis of data analysis, interpretation and discussion of the paper:

1) Do you believe that language learning advisors are needed in schools?

2) What are the general functions that a learning advisor performs or does to help learners become autonomous or independent English language learners?

3) Have you been a language advisor in addition to a language teacher (formally or informally)?

4) When you were a language advisor, about what did you advise to your learners? How did you do the advising?

5) If you were (if you have not been a language advisor before) a language advisor, what area would you advise and how would you do it?

6) Have you tried to raise the awareness of the learners about the importance of language learning process?

7) What are the general functions that a learning advisor performs or does to help learners become autonomous or independent English language learners?

8) Have you tried to guide your learners on how to learn English autonomously and effectively? How?

9) Have you tried to help your learners to identify their learning goals? In what way?

10) In your class of whatever course / subject matter you taught, have you tried to suggest suitable materials (matching learners' needs) by offering choices rather than telling them what to learn and what to do?

11) In your role as a language advisor, have you motivated, supported and encouraged your learners to be self-directed learners? How did you do it?

12) Have you ever helped your learners to do self-evaluaione and reflection on their language learning?

13) Have you tried to assist your learners or students in discovering or finding out how they best learn English?

14) As a language advisor, were you actively listening to learners' voices?

15) As a language advisor who is very concerned about your learners' language larning problems, have you tried to help learners to talk through their own problems?

16) If so, did you try to give them solutions for their learning problems or help them discover their own solutions?

17) How did you find to be a language advisor?

18) Do you think every school / university need to have formal language advisor or embedded within the roles or functions of a language teacher?

Thank you for your kind cooperation. 